\title{
COST-EFFECTIVENESS OF VANCOMYCIN POWDER FOR DEEP WOUND INFECTION PROPHYLAXIS IN SPINE FUSION
}

\author{
RELAÇÃO DE CUSTO-EFIÁCIA DE VANCOMICINA EM PÓ PARA PROFILAXIA DA INFECÇÃO \\ DE FERIDA PROFUNDA NA FUSÃO ESPINHAL
}

\author{
RELACIÓN DE COSTO-EFICACIA DE LA VANCOMICINA EN POLVO PARA PROFILAXIS DE LA \\ INFECCIÓN DE HERIDA PROFUNDA EN LA FUSIÓN ESPINAL
}

\author{
Alonso Alemán-Villalón, ${ }^{1}$ Alfredo Javer Moheno-Gallardo, ${ }^{2}$ Eulalo Elzalde-Matínez, ${ }^{2}$ Jorge Quiroz-Willams, ${ }^{1}$ Jorge Alvaro González-Ross ${ }^{3}$ \\ 1. Hospital "Dr. Victorio de la Fuente Narváez" IMSS, High Specialty Medical Unit - Trauma, Ciudad de México, México. \\ 2. Hospital "Dr. Victorio de la Fuente Narváez" IMSS, High Specialty Medical Unit - Orthopedics, Ciudad de México, México. \\ 3. Hospital Ángeles del Carmen, Department of Orthopedic Surgery, Guadalajara Jalisco, México.
}

\begin{abstract}
Objective: To identify the cost effectiveness of vancomycin powder in the prophylaxis of posterior lumbar spine instrumentation, seeking potential savings. Methods: A retrospective, observational study was performed to evaluate the cost effectiveness. Data were retrieved from patients' files from March 2016 to April 2017; costs were considered for the procedures, as well as which antibiotic was used. Results: A total of 184 patients were included. Of these, 102 received prophylactic treatment with $1 \mathrm{~g}$ of cephalothin and 82 received $1 \mathrm{~g}$ of cephalothin and $1 \mathrm{~g}$ of vancomycin powder, which was applied to the wound prior to tissue closure. Of the 184 patients, 110 were women (59\%) and 74 were men (41\%), and the mean age was 55 years (24-77). The participants had a median BMl of $28.9 \mathrm{~kg} / \mathrm{m}^{2}$ (19-39). The average cost per hospitalized patient was $\$ 3974$ USD and the average cost of rehospitalization due to infection was, on average, $\$ 7700$ USD. The use of vancomycin powder led to cost savings of $\$ 75,008.79$ USD per 100 posterior spinal fusions performed for degenerative spine. Conclusion: The use of vancomycin powder is a cost-effective option for prophylaxis of surgical site infection in spine fusion. Level of evidence III; Economic and decision analysis.
\end{abstract}

Keywords: Antibiotic Prophylaxis; Vancomycin; Cost-Effectiveness Analysis; Spinal Fusion.

\section{RESUMO}

Objetivo: Identificar a relação de custo-eficácia da vancomicina em pó como profilaxia da instrumentação posterior da coluna lombar, buscando possíveis economias. Métodos: Foi realizado um estudo retrospectivo e observacional para avaliar a relação custo-eficácia. Os dados foram recuperados dos arquivos dos pacientes de março de 2016 a abril de 2017; foram considerados os custos dos procedimentos, bem como o antibiótico usado. Resultados: Um total de 184 pacientes foi incluído, dos quais 102 receberam tratamento profilático com 1 $\mathrm{g}$ de cefalotina e 82 receberam $1 \mathrm{~g}$ de cefalotina e $1 \mathrm{~g}$ de vancomicina em pó, que foi aplicada na ferida antes do fechamento do tecido. Dos 184 pacientes, 110 eram mulheres (59\%) e 74 eram homens (41\%), e a média de idade foi de 55 anos (24-77). Os pacientes tinham IMC médio de 28,9 kg m² (19-39). O custo médio por paciente hospitalizado foi US\$3.974 e o custo médio de reinternação por infecção foi, em média, US\$ 7.700. O uso de vancomicina em pó levou a uma redução de custos de US\$75.008,79 referentes a 100 fusões que seriam realizadas nos casos de degeneração da coluna. Conclusões: O uso de vancomicina em pó é uma opção de baixo custo para a profilaxia da infecção do sítio cirúrgico na artrodese de coluna. Nível de evidência III; Análise econômica e de decisão.

Descritores: Antibioticoprofilaxia; Vancomicina; Custo-Efetividade; Fusão Vertebral.

\section{RESUMEN}

Objetivo: Identificar la relación de costo-eficacia de la vancomicina en polvo como profilaxis de la instrumentación posterior de la columna lumbar, buscando posibles economías. Métodos: Fue realizado un estudio retrospectivo y obsenvacional para evaluar la relación costo-eficacia. Los datos fueron recuperados de los archivos de los pacientes de marzo de 2016 a abril de 2017; fueron considerados los costos de los procedimientos, bien como el antibiótico usado. Resultados: Fue incluido un total de 184 pacientes, de los cuales 102 recibieron tratamiento profiláctico y $1 \mathrm{~g}$ de cefalotina y 82 recibieron $1 \mathrm{~g}$ de cefalotina y $1 \mathrm{~g}$ de vancomicina en polvo, que fue aplicada en la herida antes del cierre del tejido. De los 184 pacientes, 110 eran mujeres (59\%) y 74 eran hombres (41\%), y el promedio de edad fue de 55 años (24-77). Los pacientes tenían IMC promedio de 28,9 kg/m2 (19-39). El costo promedio por paciente hospitalizado fue de USD 3.974 y el costo promedio de reinternación por infección fue, en promedio, de USD 7700. El uso de vancomicina en polvo llevó a una reducción de costos de USD 75.008,79 referentes a 100 fusiones que serían realizadas en los casos de degeneración de la columna. Conclusiones: El uso de vancomicina en polvo es una opción de bajo costo para la profilaxis de la infección del sitio quirúrgico en la artrodesis de columna. Nivel de evidencia III; Análisis económico y de decisión.

Descriptores: Profilaxis Antibiótica; Vancomicina; Costo Efectividad; Fusión Vertebral. 


\section{INTRODUCTION}

Surgical site infection (SSI) is one of the most common and potentially devastating complications in spine surgery. ${ }^{1,2}$ Its incidence varies depending on various factors, and it is estimated that between $2.8 \%$ and $11.9 \%$ of patients undergoing spinal surgery will suffer SSI, despite the application of conventional prophylactic strategies. ${ }^{3}$

Deep spinal infection is also associated with higher costs of morbidity, mortality and health care, at an estimated cost of between 1 and 10 trillion dollars annually. ${ }^{1}$ The treatment of SSI involves considerable costs, due to prolonged hospitalization time, the use of diagnostic methods, interventions and treatment with intravenous antibiotics, among other things. ${ }^{4,5}$

Surgeons should make a great effort to minimize the risk factors for wound infection after spine surgery. ${ }^{6}$ Reported risk factors for increased rates of deep infection include advanced patient age, obesity, malnutrition, prolonged surgical time, surgery review, increased blood loss, smoking, use of instrumentation, and revision surgery. ${ }^{7}$

SSI is traditionally managed with first-generation cephalosporins or clindamycin prophylaxis, which should be administered within one hour prior to the surgical incision and discontinued within the first twenty-four hours after completion of the surgical procedure. ${ }^{8}$

Staphylococcus aureus is the organism most frequently associated with this type of infection, and with the notable increase of Methicillin-resistant S. aureus microorganisms, this type of infection has been difficult to treat. ${ }^{8}$

The powder forms of antibiotics, which are applied directly in the spinal surgical wound before closure, are effective in reducing postoperative deep bone marrow wound infection. ${ }^{4}$ They may also provide the highest levels of intralesional antibiotics for a prolonged period of time after operation. ${ }^{2}$

The application of vancomycin in the surgical wound prior to closure as a form of prophylaxis in spinal surgery has gained popularity, ${ }^{9}$ due to its bactericidal mechanism of inhibition of cell wall biosynthesis in gram-positive bacteria. It works by inhibiting the synthesis of RNA and the formation of long polymers in the cell wall, thus altering the permeability of the cell membrane. ${ }^{8}$

On the other hand, Sweet et al. ${ }^{10}$ reported that the application of vancomycin under the muscular fascia can lead to concentrations within the surgical site up to a thousand times greater than the mean inhibitory concentration for Methicillin-Resistant S. Aureus (MRSA). Its microbicide spectrum also includes other Gram-positive microorganisms, such as Staphylococcus epidermidis and Enterococcus spp., which can also cause postsurgical infection. 6,11

Currently, there is no recommended dosage for the application of vancomycin in the surgical site; different studies has reported a range of doses from $500 \mathrm{mg}$ to $6 \mathrm{~g}$; however, the most studied dose is $1 \mathrm{~g}$.

The use of local vancomycin powder has resulted in a significant decrease in postoperative infection in patients with spinal instrumentation. ${ }^{12}$ However the use of local vancomycin powder does not reduce the incidence of postsurgical infection after 30 days in patients submitted to postsurgical spinal fusion due to deformity. ${ }^{13}$

A study by Murphy et al., ${ }^{14}$ found no side effects, but a study by Ghobrial et al., ${ }^{15}$ found a complication rate of $0.3 \%$, the most frequent one being seroma with negative cultures, with 19 cases, one case of nephropathy, two cases of ototoxicity (transient hearing loss), and one case of systemic absorption, out of a total of 6701 cases treated.

\section{METHODS}

We reviewed the patients' physical and electronic clinical records, capturing those of patients with lumbar spine fusion in the period March 2016 to April 2017. These patients were followed up for one year to monitor for the development of deep tissue infection of the surgical site, and to determine which prophylaxis was used. All the patients signed an Informed Consent Form.

The cost-effectiveness analysis was carried out, taking into account the costs of the drugs obtained by competitive tender in 2018 , published on the official website of the IMSS in the section: "IMSS bought", in which the price of Cephalothin powder is equivalent to 1 gram in \$19 (approximately \$1 USD), vancomycin powder equivalent to $1 \mathrm{~g}$ in $\$ 85.1$ (\$4.5 USD).

The process that has been carried out for several years in the Orthopedic spine department is that the patient is admitted two days prior to the surgical procedure; a dose of 1 gram of Cephalothin is applied 30 minutes prior to surgery, as well as additional dose, depending on time (> 2 hours) and bleeding (> 500 cc) during surgery. Two further doses are applied postoperatively.

The objective of this study is to determine whether the application of 1 gram of vancomycin in the deep soft tissues prior to wound closure is a cost-effective prophylactic measure. For this, it calculates the potential savings of using vancomycin to prevent surgical site infection. Taking into account an average procedure in which the prophylactic dose of cephalothin is used, plus the booster dose and two further postsurgical doses, a total of 4 grams of cephalothin is administered, which according to the price listed, corresponds to a cost of $\$ 4.05$ USD. The use of 1 gram of topical vancomycin prior to wound closure corresponds to a cost of \$4.53 USD.

Two groups were compared; the first received conventional prophylaxis and the second received one gram of vancomycin prior to wound closure. The aim was to compare the infection rates of both groups and to determine the impact of the application of vancomycin in reducing the rate of infection, thereby lowering hospitalization costs and the need for treatment for SSI. The statistical analysis was carried out using SPSS 23 from a Microsoft EXCEL spreadsheet database. The study was approved by the ethics committee, under number: R-2018-3401-015

\section{RESULTS}

We studied a total of 184 patients who underwent posterior lumbar instrumentation in the period March 2016 to April 2017. Out of the 184 patients, 74 (40.9\%) were men and 110 were women (59.1\%). The mean age was 55 years. (Table 1 ) Also $51 \%$ of the population had some comorbidity, as reported in Figure 1, the most frequent being systemic hypertension, followed by diabetes mellitus.

In all cases, the patients received Cephalothin 30 minutes prior to the surgical incision, plus a booster dose and two further postsurgical doses, with their respective reinforcement doses according to time and surgical bleeding, as they set up antibiotic prophylaxis guidelines. Of these 184 patients, 82 received the additional $1 \mathrm{gram}$ of vancomycin powder in deep tissues at the time of wound closure. In the remainder (102 patients), the conventional protocol was applied.

On average, two levels were fused, with L5-S1 being the most

Table 1. Demigrahpics.

\begin{tabular}{c|c|c|c}
\hline Variable & Minimum & Maximun & Mean \\
\hline Age (years) & 24 & 77 & 55 \\
\hline Bmi (kg/m2) & 19 & 39 & 28,9 \\
\hline Spinal fusion levels & 2 & 8 & 2,4 \\
\hline Bleeding (cc) & 100 & 3000 & 761 \\
\hline Surgical time (minutes) & 80 & 720 & 280 \\
\hline
\end{tabular}

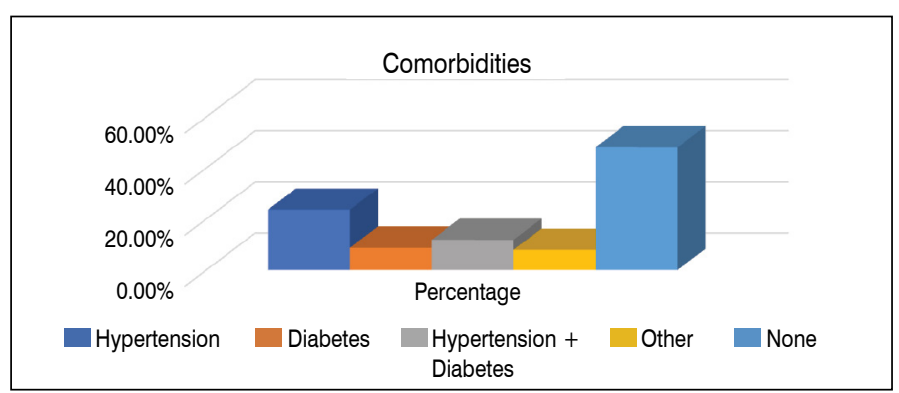

Figure 1. Comorbidities. 
common. The average bleeding reported was $761 \mathrm{cc}$; average surgical time of 280 minutes; and $98 \%$ of the patients were fitted with a drain for 2 days.

Of the 184 patients, 12 patients developed an SSI (6.5\%); 10 with conventional prophylaxis and 2 in the vancomycin group, resulting in $9.8 \%$ vs $2.4 \%$, with a statistically significant $p$ value $>0.05$ by the $\mathrm{Chi}^{2}$ test. (Figure 2)

Considering more specifically those patients in whom there was SSI is shown in Table 2. All patients were metabolic stability prior to their surgical intervention. An average body mass index of 30.77 was obtained, which indicates grade I obesity. There was an average of 3 instrumental levels, trans-surgical bleeding of $1030 \mathrm{cc}$, and average surgical time of 5 hours 30 minutes.

Among the microorganisms isolated by culture, we recorded 4 cases of $\mathrm{E}$. coli followed by 2 cases of MRSA. The rest are shown in Figure 3.

Of the 12 patients, 10 received an antibiotic prophylaxis regimen based on Cephalothin, one was managed with Trimethoprim/Sulfamethoxazole and one with Ciprofloxacin.

The symptoms manifested at the follow-up visits where mainly exudation through the wound, which manifested within an average of 15 days after discharge (5-20 days) in 9 patients. Two patients had symptoms after 40 days, while one patient showed symptoms

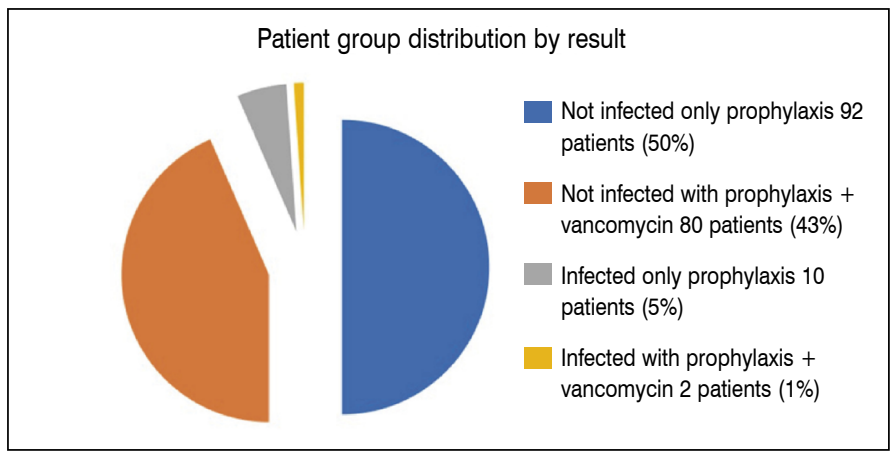

Figure 2. Patient group distribution by result.

Table 2. Demographics of the infected patients

\begin{tabular}{c|c|c|c}
\hline & Minimum & Maximum & Mean \\
\hline Age (years) & 40 & 76 & 60 \\
\hline Bmi (kg/m2) & 24,1 & 38,3 & 30,7 \\
\hline Numer of levels fused & 2 & 8 & 3,2 \\
\hline Bleeding (cc) & 450 & 2000 & 1030 \\
\hline Time (minutes) & 240 & 720 & 330 \\
\hline $\begin{array}{c}\text { Days since hospital discharge until } \\
\text { begining of infection symptoms }\end{array}$ & 5 & 310 & 43 \\
\hline Days of intrahopsital stay & 7 & 30 & 15 \\
\hline
\end{tabular}

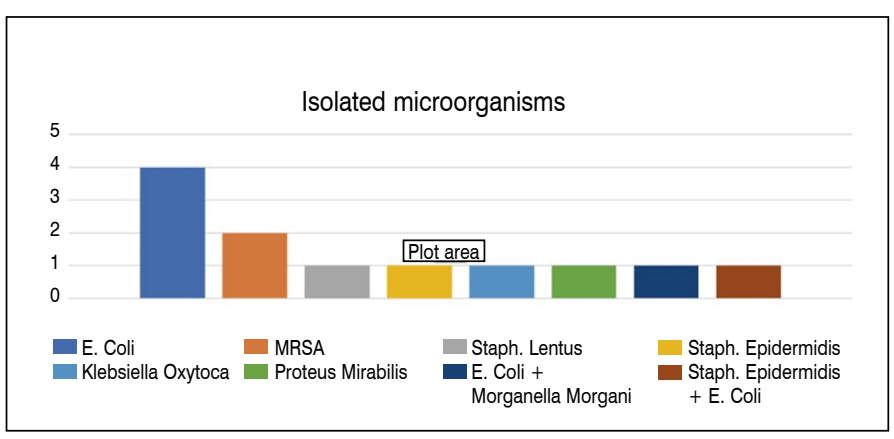

Figure 3. Isolated microorganisms. after 310 days. The average hospital stay of the patients was 15 days; during this period, they were treated with specific antibiotics, based on the culture sample taken during the debridement surgery. Eight patients were treated with a single debridement surgery; only one patient required a second surgery. Three patients were treated only with a wide-spectrum antibiotic.

According to the department's protocol, a patient is hospitalized for an average of 5 days ( 2 prior to the surgery, the day of the surgery, and 2 days post-surgery).

Taking as reference the "ACDO Agreement". AS3. HCT. 291117/275. P. DF and its annexes, dictated by the H. Technical Council at the ordinary session held on November 29, 2017, concerning the approval of unit costs per level of medical care updated in 2018, this represents to the institute a cost of hospitalization of \$2,066 USD (\$413 USD per day), \$9.7 USD per clinical laboratory study, since a biometric hematic of control is always requested 24 hours after surgery, \$1,916 USD per surgical intervention, and $\$ 22$ USD per Blood Bank service, giving an approximate total of $\$ 4,014$ USD per hospitalization. This does not include the costs of the implants, or general overheads, such as electricity, gas, and cleaning and use of soil.

In relation to the antibiotic treatment, prophylaxis with cephalothin, considering a total of 5 doses (1 pre-operative, 1 trans-operative, and 3 post-operative) is shown on Table 3.

While according to the infected patients their re-entry represented for the institute a total of 180 days of hospital stay, resulting in an expense per hospitalization of \$74,387.86 USD; \$350.99 USD for laboratory studies, including complete blood count and culture from the site of infection (an average of 3 laboratory studies per patient); \$17.25 USD of surgical interventions since 8 patients underwent surgical debridement and another 2 procedures; $\$ 263.40$ USD since some required a blood transfusion to improve postoperative conditions

Readmitted patients were treated with specific antibiotics, based on the reported antibiogram obtained from the cultures. The antibiotics used in these 12 patients were Ciprofloxacin, Linezolid, Meropenem, Ceftriaxone, Cephalothin, Cefotaxime, Clindamycin and Amikacin.

According to the cost of antibiotics and the doses used in these 12 patients, the total expenditure on antibiotics, for the institute, was $\$ 1,317.03$ USD, as shown in Table 4.

The hospital readmission cost of these 12 infected patients represented approximately $\$ 93,341.28$ USD; an average of $\$ 7700$ USD per patient. (Figure 4)

\section{Cost-Benefit Analysis}

The mean total infection-related cost per patient was $\$ 7700$ USD. With a $9.8 \%$ incidence of SSI in the control group, the infection-related cost per 100 spinal fusions was $\$ 75,460$ USD. The cost of vancomycin powder administered to a single patient was $\$ 4.5$.

Table 3. Prophylactic antibiotic costs.

\begin{tabular}{c|c|c|}
\hline Antibiotic & Single dose cost & $\begin{array}{c}\text { Phophylactic } \\
\text { antibiotic cost }\end{array}$ \\
\hline Cephalotin & 1.01 & 5 \\
\hline Ciprofloxacin & 0.44 & 2.20 \\
\hline Trimethoprim/sulfamethoxazole & 2.26 & 11.29 \\
\hline
\end{tabular}

Table 4. Antibiotic costs in infected patients.

\begin{tabular}{c|c|c|}
\hline Antibiotic & Days & Cost in USD \\
\hline Ciprofloxacin & 24 & 208.53 \\
\hline Cephalotin & 40 & 160.08 \\
\hline Linezolid & 7 & 92.49 \\
\hline Meropenem & 44 & 766.54 \\
\hline Ceftriaxone & 23 & 26.15 \\
\hline Trimethoprim/sulfamethoxazole & 5 & 18.07 \\
\hline Clindamycin & 6 & 5.21 \\
\hline Amikacin & 25 & 39.96 \\
\hline Total & & 1317.03 \\
\hline
\end{tabular}




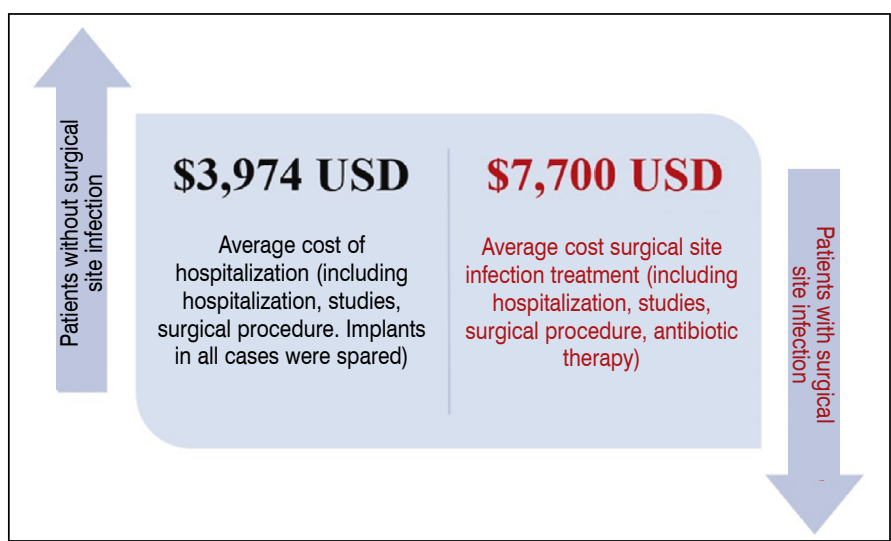

Figure 4. Overall average costs for patients with and without surgical site infection.

The cost of using vancomycin powder per 100 spinal fusions was $\$ 451.21 \mathrm{USD}$. Therefore, if we round up the infection rate to $10 \%$ vs $3 \%$, and considering a group of 100 patients, we obtain; $((10 * 7700)$ $+(90 * 3974))-((3 * 7700)+(98 * 3974))->434,600-404,816=$ $\$ 29,784$ USD saved for every 100 patients treated with vancomycin.

\section{DISCUSSION}

In recent years, the application of vancomycin powder in the wound, as part a compliment to traditional prophylaxis, has gained popularity as it appears to effectively reduce the infection rate, as well as being a low-cost antibiotic that can be applied in a single dose.

In this study, we set out to determine the cost-effectiveness of using vancomycin powder at the surgical sites to prevent postoperative infection. The control group received standard systemic prophylaxis with Cephalothin, while the treatment group received $1 \mathrm{~g}$ of local vancomycin powder in addition to systemic prophylaxis. Our results demonstrate that the use of local vancomycin powder led to a significant reduction in the rate of surgical site infection, from $9.8 \%$ in the control group to $2.4 \%$ in the treatment group. Furthermore, it led to cost savings of around $\$ 75,460$ USD per 100 spinal fusions performed, considering that all patients maintained the implants.

In our series, similar to the results reported by Murphy et al. ${ }^{14}$ we encountered no negative side effects, which is consistent with the low incidence reported by Ghobrial et al., ${ }^{15}$ and we consider it safe to use, although with caution, monitoring for the rare side effects reported by Ghobrial. ${ }^{15}$

We believe the increase in popularity of vancomycin for use in this context is because it comes in powder form, allowing for it to be spread evenly in the deep tissue, its low hospital cost, and its broad and effective spectrum against bacteria found in SSIs. ${ }^{10}$

So far, iv application of vancomycin has not been proven to decrease the infection rate compared to traditional prophylaxis with iv cephalosporins, but it has been associated with side effects such as red man syndrome, hypotension and ototoxicity, and increased risk of resistant organisms. ${ }^{16}$

With the increasing presence of $\mathrm{MRSA}^{9}$ amongst other resistant microorganisms in SSI, and the increase in direct and indirect costs of treating patients, both to the hospital as well as to patients; the application of local vancomycin powder is a cost-effective option for use in the prophylaxis of SSI in spine surgery.

This study does not include the cost of out-patient medical resources (e.g. long-term use of antibiotics, physician visits, and diagnostic tests), nor those it includes the cost of implant removal, since the implants were maintained in all the patients of our series. Therefore infection-related cost savings might be even greater than reported in this study when these costs are taken into consideration.

\section{CONCLUSIONS}

Surgical site infection is one of the most common complications in surgical procedures, but can often be mitigated by precautionary measures, such as the prophylactic use of antibiotics.

Adjuvant use of vancomycin powder was associated with a lower infection rate compared to the traditional systemic of prophylaxis alone. Also, considering the cost of a single $1 \mathrm{~g}$ dose of vancomycin versus the cost for treating an infected patient, it proved to be a costeffective alternative. This results in lower expenses for the Institute, as well as a shorter hospitalization times, and faster reintegration for the patient into their daily activities.

All authors declare no potential conflict of interest related to this article.

CONTRIBUTION OF THE AUTHORS: Each author made significant individual contributions to this manuscript. AAV: Data management, result interpretation, paper writing; AMG: critic reading, protocol design, result interpretation; EEM: critic reading, result interpretation; JQW: protocol design; JAGR: result interpretation, critic reading, paper writing.

\section{REFERENCES}

1. Schuster JM, Rechtine G, Norvell DC, Dettori JR. The influence of perioperative risk factors and therapeutic interventions on infection rates after spine surgery: A systematic review. Spine (Phila Pa 1976). 2010;35(9 Suppl):S125-37. doi: 10.1097/BRS.0b013e3181d8342c.

2. Calderone RR, Garland DE, Capen DA, Oster $\mathrm{H}$. Cost of medical care for postoperative spinal infections. Orthop Clin North Am. 1996;27(1):171-82

3. Martin JR, Adogwa O, Brown CR, Bagley CA, Richardson WJ, Lad SP, et al. Experience with intrawound vancomycin powder for spinal deformity surgery. Spine (Phila Pa 1976). 2014;39(2):177-84. doi: 10.1097/BRS.0000000000000071.

4. Hill BW, Emohare O, Song B, Davis R, Kang MM. The use of vancomycin powder reduces surgical reoperation in posterior instrumented and noninstrumented spinal surgery. Acta Neurochir (Wien). 2014;156(4):749-54. doi: 10.1007/s00701-014-2022-z.

5. Strom RG, Pacione D, Kalhorn SP, Frempong-Boadu AK. Decreased risk of wound infection after posterior cervical fusion with routine local application of vancomycin powder. Spine (Phila Pa 1976). 2013;38(12):991-4. doi: 10.1097/BRS.0b013e318285b219.

6. Molinari RW, Khera OA, Molinari WJ. Prophylactic intraoperative powdered vancomycin and postoperative deep spinal wound infection: 1,512 consecutive surgical cases over a 6-year period. Eur Spine J. 2012;21 (Suppl 4):S476-82. doi: 10.1007/s00586-011-2104-z.

7. Dubory A, Giorgi H, Walter A, Bouyer B, Vassal M, Zairi F, et al. Surgical-site infection in spinal injury: incidence and risk factors in a prospective cohort of 518 patients. Eur Spine J. 2015;24(3):543-54. doi: 10.1007/s00586-014-3523-4.

8. Kang D, Holekamp T, Wagner S, Lehman R. Intrasite vancomycin powder for the prevention of surgical site infection in spine surgery: a systematic literature review. Spine J. 2015;15(4):762-70. doi: 10.1016/j.spinee.2015.01.030

9. Ross JAG, Gallardo AJM, Martinéz EE, Atanasio JMP, Martinez RM. Intrasite van- comycin powder as a prophylactic adjuvant in lumbar fusion. Coluna/Columna 2016;15(1):44-7. doi: 10.1590/S1808-185120161501154501.

10. Sweet FA, Roh M, Silva C. Intrawound application of vancomycin for prophylaxis in instrumented thoracolumbar fusions: efficacy, drug levels, and patient outcomes. Spine (Phila Pa 1973). 2011;36(24):2084-8. doi: 10.1097/BRS.0b013e3181ff2cb1.

11. Chua K, Howden BP. Treating Gram-positive infections: vancomycin update and the whys, wherefores and evidence base for continuous infusion of anti-Gram-positive antibiotics. Curr Opin Infect Dis. 2009;22(6):525-34. doi: 10.1097/0C0.0b013e328331fbcd.

12. Kim HS, Lee SG, Kim WK, Park CW, Son S. Prophylactic intrawound application of vancomycin powder in instrumented spinal fusion surgery. Korean J Spine. 2013;10(3):121-5. doi: 10.14245/kjs.2013.10.3.121.

13. Martin JR, Adogwa O, Brown CR, Bagley CA, Richardson WJ, Lad SP, et al. Experience with intrawound vancomycin powder for spinal deformity surgery. Spine (Phila Pa 1976). 2014;39(2):177-84. doi: 10.1097/BRS.0000000000000071.

14. Murphy EP, Curtin $M$, Shafqat $A$, Byrne $F$, Jadaan $M$, Rahall $E$. A review of the application of vancomycin powder to posterior spinal fusion wounds with a focus on side effects and infection. A prospective study. Eur J Orthop Surg Traumatol. 2017:27(2):187-91. doi: 10.1007/s00590-016-1878-4

15. Ghobrial GM, Cadotte DW, Williams K Jr, Fehlings MG, Harrop JS. Complications from the use of intrawound vancomycin in lumbar spinal surgery a systematic review. Neurosurg Focus. 2015;39(4):E11. doi: 10.3171/2015.7.FOCUS15258

16. Kanj WW, Flynn JM, Spiegel DA, Dormans JP, Baldwin KD. Vancomycin prophylaxis of surgical site infection in clean orthopedic surgery. Orthopedics. 2013:36(2):138-46. doi: 10.3928/01477447-20130122-10. 